\title{
Market entry agility in the process of enhancing firm performance: A dynamic capability per- spective
}

\section{Nilna Muna ${ }^{a}$, Ni Nyoman Kerti Yasa ${ }^{b^{*}}$, Ni Wayan Ekawati ${ }^{b}$, I Made Artha Wibawa ${ }^{b}$, Anak Agung Ayu Sriathi ${ }^{\mathrm{b}}$ and I Nyoman Rasmen Adi}

${ }^{a}$ Phd Student, Faculty of Economics and Business, Udayana University, Indonesia

${ }^{b}$ Faculty of Economics and Business, Udayana University, Bali, Indonesia

${ }^{c}$ Faculty of Economics and Business, Universitas Pendidikan Nasional, Bali, Indonesia

\section{H R O N I C L E \\ A B S T R A C T}

Article history:

Received: June 18, 2021

Received in revised format: July 29, 2021

Accepted: September 28, 2021

Available online: September 28, 2021

Keywords:

Social media

Market entry agility

Product innovativeness

Business strategic

Firm performance

\begin{abstract}
Social media empowers small and medium enterprises (SMEs) in engaging with their stakeholders economically and effectively. Social media use affects SMEs operation and knowledge sharing which creates innovation opportunities, speeds time to market, satisfies firm's customers, and improves business performance. Current research aims to explore the impact of social media use on the market entry agility, product innovativeness, reducing the market entry time for the SME and improving the firm performance. Cross-sectional survey-based data was collected from the jewelry crafting SMEs in Bali, Indonesia. The data was analyzed with the covariance-based statistical analysis technique with the SPSS based AMOS 23. The study results identify that social media use and market entry agility significantly impact firm performance. However, product innovativeness insignificantly influences firm performance. Furthermore, the market entry agility mediates for the firm performance so, SMEs need to leverage social media use, and market entry agility enables the dynamic capacity to enhance firm performance. Firms' level innovativeness capability should be considered as a mediating role but should support another variable to leverage firm performance. The study limitation and future research options are reported at the end.
\end{abstract}

(C) 2022 by the authors; licensee Growing Science, Canada.

\section{Introduction}

The power of social media adoption in leveraging performance is still attracting marketing and management academics. Organizations, users, customers, and institutions all strategically use social media. Through social media, businesses have been connecting with stakeholders for over a decade. Some of the benefits of social media use could be seen in several ways such as improve target reach, relationship with customers and get useful consumers' insights (Jones, Borgman, \& Ulusoy, 2015) and enhance firm performance (Alhaimer, 2021). Social media is becoming increasingly significant for individuals and businesses within the innovation community and corporate levels to use it. Firms' get benefit from the flexibility of communication, collaboration, and innovation have been influenced by social media. Traditional communication barriers are broken down through the flexibility of information technology enabled social media tools. Some businesses have begun to incorporate social media as a tool for open innovation. (Mount \& Martinez, 2014). Social media technologies have impacted organizational processes and contributed to the development ability and capability building. Some previous research (GarciaMorales, 2018) described how social media usage directly impacts business success. Social media adoption is tools that

* Corresponding author.

E-mail address: kertiyasa@unud.ac.id (N.N.K. Yasa)

(C) 2022 by the authors; licensee Growing Science, Canada. doi: $10.5267 /$ j.ijdns.2021.9.018 
utilize in the selling activities, indicated by, among others, sharing content (Al-Rawabdeh, Ghadir, \& Al-Abdallah, 2021), create conversation, create social relationships, manage a community (Foltean, Trif, \& Tuleu, 2018) and taking good care of customers, and believing that every consumer concern is essential to the company, providing personalized service to every customer (Trainor, Andzulis, Rapp, \& Agnihotri, 2014). Customer loyalty and retention, sales and revenue growth, improved customer satisfaction, brand recognition and reputation building are all possible outcomes of social media usage. Research has shown that social media adoption's influence on business performance varies; some studies show the beneficial impact of social media adoption on firm performance (Tajvidi \& Karami, 2017; Yasa et al., 2021). On the other side, Some research shows that social media usage has no direct impact on firm performance (Ahmad, Abu Bakar, \& Ahmad, 2019; GarridoMoreno, García-Morales, King, \& Lockett, 2020) Consumer perception of value as well as good word-of-mouth (Zollo, Filieri, Rialti, \& Yoon, 2020). As such, the study of (Pratono, 2018) the entire model demonstrates that social media usage has an indirect effect on a company's sales performance, except through a variety of mediation methods. Due to conflicting findings on the influence of social media adoption on business performance, this study attempts to explain alternative methods for bridging the gap associated with social media adoption in order to boost firm performance, with a better usage of social media, the perceived business value will be strengthened, and this will eventually increase the business performance (Yasa, et al., 2020). Dynamic capability is one of the main pillars in marketing studies that view market entry agility and product innovativeness-borrowing from Teece (2007) SM tools as influencing factors on the dynamic capabilities of the focus company to create business value sensing, seizing and reconfiguring knowledge in the penetration to new market \& innovation process. We adopted a dynamic capabilities approach (David J. Teece, 2017) to bridge the gap between previous research on social media use and corporate performance for several reasons. Firstly, a marketing strategy must have capabilities that highlight strategic management's role in adapting, integrating, and reconfiguring organizational skills, resources, and functional competencies (Hunt \& Madhavaram, 2019). The more advanced the value processing and delivery capabilities, the greater the chance of encouraging customers and consumers to invest in creating advanced capabilities. Secondly, it should be seen as the dynamic term, when time-to-market and timeliness are important, innovation is increasing, future competition and markets are uncertain, specific strategic solutions are needed, and a product or service should be developed and provided to the targeted market with a benefit. A firm should endeavor to increase its capabilities, integrate and re-compose resources to generate new value creation methods for the target market (Eisenhardt, 2000). Thirdly, A value generated and brought to a target market should arise from the alignment of production and marketing activities to strategically optimize social media capabilities. The purpose of this study is to bridge social media adoption firm performance by inserting several dynamic capability-related concepts of market entry agility and product innovativeness. The conceptual framework tested the SME's creative industry for handicraft \& design service in the Jewelry industry in Bali - Indonesia.

\section{Literature review}

\subsection{Social media adoption, market entry agility and firm performance}

Market entry is essential as a strategic time to enter the market for business growth and sustainability for every business (Vassolo, GarcíA-SÁNchez, \& Mesquita, 2017). Previous research Studies indicated that many factors could enhance market entry. For example, adapted to new technology (Neirotti, Raguseo, \& Paolucci, 2018), product innovativeness (Presutti, Cappiello, \& Johanson, 2020), speeding to fit market needs \& trend (Trivedi, Trivedi, Goswami, \& Sciences, 2018), early entrance the competitor (Flor \& Moritzen, 2020), to be quick getting access to the market (Damarwulan \& Farida, 2018) and back office support readiness (Cenamor, Rönnberg Sjödin, \& Parida, 2017) are considered as the attribute of market entry for strengthening the strategic entry agility, to grow business opportunity and gain more customer is vital for building ways for increasing competitiveness (Zhou, Zhang, Zhuang, \& Zhou, 2015). Strategic entry efficiently extends to agility in market entrance, where the business operates, and depends on its existence to gain resources for competitive advantage (Hunt \& Madhavaram, 2006). It must enable the business owners to satisfy customer needs more and more effectively than their competitors to achieve a competitive advantage (Hunt \& Morgan, 1995). When the companies are shifting to digital technology, they will become more efficient and effective for gaining a comparative advantage (Spralls, Hunt, \& Wilcox, 2011). Market entry agility is postulated as a hub of potential value-adding the ability to manage \& execute business strategy (Gupta, Kumar, Grewal, \& Lilien, 2019; J. Zhang \& Du, 2019) for empowering business processes and enhancing business performance. Only if this entry capability provides any agility to improve the business process is considered a strategic resource for gaining strategic advantages. In this line, the entry agility is mirrored by the effectiveness of prior knowledge, network ties (Rezvani, Lashgari, \& Yadolahi Farsi, 2019) and the success of getting market access (Damarwulan \& Farida, 2018) and readiness for Back Office support. The speeding to fit the market needs, could create agility as the entry quality to catch up the opportunity our product to be first in the market may build a value-oriented pioneer. Agility to understand \& fulfilling market needs (Hunter, 2014) may arise from being first in the market, such as introducing new products quickly before competitors as a driver for growth and performance. As in the core philosophy of dynamic capability (Shelby, 2010; Spralls et al., 2011) dynamic capability would be a company strategic resource (Hunt \& Madhavaram, 2019), as a high-impact on new market entry would be a kernel of agility for enhancing business processes and performance. A market entry triggered by social media (Nash, 2019) holds potential for enhancing competitive advantages. Therefore, a market entry agility is understood as a company's capacity to create a high-impact business process as leveraged by the use of social media technology and product innovativeness that lead to a firm performance. Based on the description above, the hypothesis can be proposed as: H1: Social media adoption has a positive impact on the market entry agility. 
Defining agility as a capability or in terms of strategic resources, researchers often focus on such direct or function-specific performance outcomes as speeding meeting customer expectations, getting new products to market quickly, speeding getting market access, and back office support readiness making sure to move into as well as out of strategic early market entry (Kim, 2018). All are more difficult to manage in dynamic business environment, dynamic of market trend (Guo, Wang, Hao, \& Saran, 2018) and short product life cycle, level of competition and heterogeneity (Sears, 2019), all of which lead to customer satisfaction and ultimately influence competitive advantage (Jimi \& Shijin, 2016). The timing strategy to enter a new market becomes the determinant of firm performance (Leih \& Teece, 2014; Zachary, Gianiodis, Payne, \& Markman, 2014). Much research has shown that any firm implementing market entry strategies can obtain other competitive and financial benefits (Li, Li, \& Cai, 2014). Vassolo et al. (2017) claimed that company strategy and competitive performance level have an influence on the dynamics of the environment and competition. In improving its performance in a highly dynamic environment, companies must be flexible and adaptive and differentiate. Meanwhile, research conducted by Claussen, Essling, and Peukert (2018) determined that performance is influenced by core flexibility abilities and competitive strategies. The following hypothesis is proposed based on previous research: H2. The ability to enter the market has a positive impact on firm performance.

\subsection{Social media adoption, product innovativeness and firm performance}

Consumers are constantly on the search for products that provide value when utilized. The emergence of information technology is shifting the consumer behavior to check everything through digital media before buying. Social media to be one of the consumer choices to check others opinion $\&$ feedback which they have interactive communication onto it (Al-Rawabdeh et al., 2021). A pervasive culture of social media technologies enables communication and data collection about consumer demands and market trends. Its resultant information may be used by businesses to improve their capability to deliver highvalue product or services to customers (Seidel, Hannigan, \& Phillips, 2020). This can be accomplished by developing an innovative product that provides a distinct competitive advantage (Ferreira \& Coelho, 2020). A product that results from an innovation process that utilizes technological advantages is known as the innovative product, which offers a competitive advantage and specific characteristics (Taneo, Hadiwidjojo, Sunaryo, \& Sudjatno, 2020). Advancements in technology boost the ability to develop innovative products, since technology-based businesses may increase efficiency and efficiency in making products (Alhaimer, 2021). Product innovation shows the development and progress of product functionality, which can provide a clear picture to the consumer that the product innovativeness produced has superior value for the consumer. Product innovation illustrates the evolution of product features (Onufrey \& Bergek, 2020). Innovative products can be described as new products, new markets, and superior products that adapt to consumers' needs. Product innovation may show the customer that the product's newness has better value (Kahle, Marcon, Ghezzi, \& Frank, 2020). Innovative products may include NEW different products(Saunila, 2020), new market opportunities (Shehata, 2020), and higher quality products (Ferreira \& Coelho, 2020)designed to meet customers' requirements . Product innovation aims to improve product performance, so the success of product innovation is highly dependent on the company's ability to produce superior value to customers. Companies with a deep market-oriented culture understand the needs and desires of customers and use it as the basis for innovative product innovation. To be successful in product innovation, a business must be able to deliver superior value to consumers. Companies with a high market-oriented culture are well in requirements and expectations of their consumers, and they utilize this knowledge as the foundation for innovative product development (Hiong, Ferdinand, \& Listiana, 2020). Thus, the performance of product innovativeness depends not only on product orientation but also on how well the company understands customer needs. Therefore, product innovativeness is measured not only by the company's ability to innovate but also by its ability to comprehend and satisfy the requirements of its customers.

The right product innovation strategy would produce an excellent performance on product innovativeness; thus, it can support firm performance. An outstanding performance on product innovativeness would be achieved by implementing the appropriate product innovation strategy; as a result, it would be able to contribute to improved firm performance (Ramadani et al., 2019). Firm performance is an indicator of the achievement of the operations of the business. Measurement of firm performance is important since the company's perspective of the success of ongoing business is affected by diverse organizational cultures and leadership styles. The results of the study carried out byBelghitar, Clark, and Kassimatis (2019), are judged by profitability, changes in profit, and changes in percentage of income. The current study concludes that the primary purpose of the company's performance is to generate value that can contribute to profitability growth, sales growth, and market share growth. Latifi, Nikou, and Bouwman (2021) performed a study in which they measured the performance of the business determined by the size of the value of profitability, sales growth, and product performance. The recent research indicates that a company's performance is intended to provide value to profit, profit percentage, sales growth, and customer growth. A previous study shows that innovation has a positive but insignificant impact on firm performance in terms of firm size (Prifti \& Alimehmeti, 2017). This is due to the payback period for the resources used in the innovation process. Product innovation policies aimed at enhancing product innovativeness can improve firm performance (Rajapathirana \& Hui, 2018). Product innovation strategies that are targeted at increasing product innovativeness have been shown to enhance firm success (Paparoidamis \& Tran, 2019). Based on the findings of previous research on the impact of innovativeness products on the firm performance, this study develops hypothesis as follows, 
$\mathbf{H}_{3}$ : Social media adoption has a positive effect on product innovativeness.

H4: Product Innovativeness has a positive effect on firm performance..

\section{Research Method}

\subsection{Material and method on Sample and data collection}

The data collection in this study came from the SME business group focused on exporting handcrafted jewelry accessories to creative industries located throughout the Bali province. This responder group is spread throughout four regencies: Denpasar, Badung, Gianyar, and Klungkung. The four districts are Indonesia's largest exporters of handcrafted jewelry, notably in the province of Bali. The owners and managers of export-oriented jewelry accessory craft SMEs are surveyed in this study. The questionnaire may be completed using Google or by filling out an online form. 248 questionnaires were returned to the researcher out of a total of 275 issued. The researcher collected data from jewelry accessories SMEs using a purposive sampling method (both managers and owners). Two respondents did not completely complete the questionnaire, and 10 respondents' data had outliers at the time of data validation, because of the data collecting findings. The original sample had 236 respondents who were representative of the research population.

\subsection{Constructs measurements}

Primary data were gathered for this study via a researcher-conducted survey. The questionnaire was created to assess the components by scoring the respondents' responses on a 1-10 scale (Sekaran, 2010). To measure the four variables, namely the use of social media technology, agility to enter the market, product innovation, and company performance, it is possible to use a rating scale. A score of 1 represents the most disagreeable answer and a score of 10 represents the most agreeable answer. The model and hypothesis testing in this study used Structural Equation Modeling (SEM) with AMOS software version 23. The study employed a measuring model to ascertain unidimensionality. The indicator is used to evaluate the quality of fit parameters. Convergent validity is used to determine if the indications are valid for testing what needs to be examined. Additionally, the indicators' significance should be evaluated to determine whether they give the same dimensions as the latent variables. We use the SEM-structural equation modeling technique because first, SEM effectively solves multiple equations compared to conventional regression analysis as in the SPSS standard package with dependent and independent variables influencing each other (Nachtigall, Kröhne, Funke, Steyer, \& Schiller, 2003) such as on our model. Secondly, SEM's simultaneous process could measure the mediational effect (Tabachnick \& Fidell, 2012). Finally, the analysis process resulted in measurement validity and reliability as exerted in Table 1.

Table 1

Measurement of validity and reliability

\begin{tabular}{|c|c|c|c|c|c|}
\hline VARIABLE \& INDICATOR & REFERENCE & $\begin{array}{l}\text { STD. LOAD- } \\
\text { ING } \\
\text { (Lambda } \\
\text { Value) }\end{array}$ & $\begin{array}{l}\text { Critical } \\
\text { Ratio } \\
\geq 1.96\end{array}$ & $\begin{array}{c}\text { CV-AVE } \\
\geq 0.50\end{array}$ & $\begin{array}{c}\text { CRI } \\
\geq 0.70\end{array}$ \\
\hline Social Media Technology Use (SMU) & \multirow{4}{*}{$\begin{array}{l}\text { Adapted from } \\
\text { (Foltean, Trif, \& } \\
\text { Tuleu, 2018) }\end{array}$} & & & 0.577 & 0.802 \\
\hline Share Content & & 0.822 & 9.914 & & \\
\hline Create Social Relationship & & 0.649 & 9.914 & & \\
\hline Manage Community & & 0.796 & 12.33 & & \\
\hline Market Entry Agility & \multirow{5}{*}{$\begin{array}{l}\text { Adapted from } \\
\text { (Damarwulan \& } \\
\text { Farida, 2018) \& } \\
\text { (Nuryakin.,2018) }\end{array}$} & & & 0.677 & 0.893 \\
\hline Fit Market needs \& trend & & 0.736 & 11.163 & & \\
\hline Faster than competitor & & 0.731 & 11.163 & & \\
\hline Quickly get market access & & 0.888 & 13.572 & & \\
\hline Back-office support readiness & & 0.919 & 13.982 & & \\
\hline Product Innovativeness & \multirow{4}{*}{$\begin{array}{c}\text { Adapted from } \\
\text { (Hiong et al., } \\
\text { 2020) \& (Ardyan., } \\
\text { 2015) }\end{array}$} & & & 0.734 & 0.892 \\
\hline Product Inimitability & & 0.836 & 15.342 & & \\
\hline Product Variability & & 0.870 & 15.342 & & \\
\hline Product Creative & & 0.863 & 15.236 & & \\
\hline Firm Performance & \multirow{4}{*}{$\begin{array}{l}\text { Adapted from } \\
\text { (Aydiner et al., } \\
\text { 2019) }\end{array}$} & & & 0.875 & 0.700 \\
\hline Market share growth & & 0.838 & 13.964 & & \\
\hline Sales growth & & 0.825 & 13.964 & & \\
\hline Profitability growth & & 0.847 & 14.283 & & \\
\hline
\end{tabular}


A total of 236 samples were selected, because this number is feasible to use as a sample size requirement using the average extracted variance (AVE) criteria, which requires a minimum sample size of 150: the estimated standard load value is less than 0.7 and greater than 0.5. (Hair et al., 1998). In addition, we identified convergent validity using composite reliability (CR) and extracted mean variance (AVE). The analysis findings (Table 1) show that all the standard factor loadings for the respective constructs were statistically significant, with the fit statistic indicating an adequate fit index for the data. The construct validity values and variance extracts in Table 1 show that the constructs of using social media technology, market entry capacity, product innovation, and business performance are valid constructs. In particular, the evaluation of the variable constructs showed the corresponding construct reliability above 0.7 , that is, the construct reliability index (CRI) was greater than 0.7 and the AVE was greater than 0.5. (Arbuckle, 2016; Tabachnick \& Fidell, 2012). A full-SEM analysis was executed to measure the model's goodness of fit and test the hypothesis. The result is presented in Figure 1 and Table 2 . Resultantly, the proposed model is well-supported with good GFI (0.948), CFI (0.985), TLI (0.981), and RMSEA (0.043). Meanwhile, the proposed research hypotheses were supported with a critical ratio $\geq 1.96$ and a significant level under 0.05 .

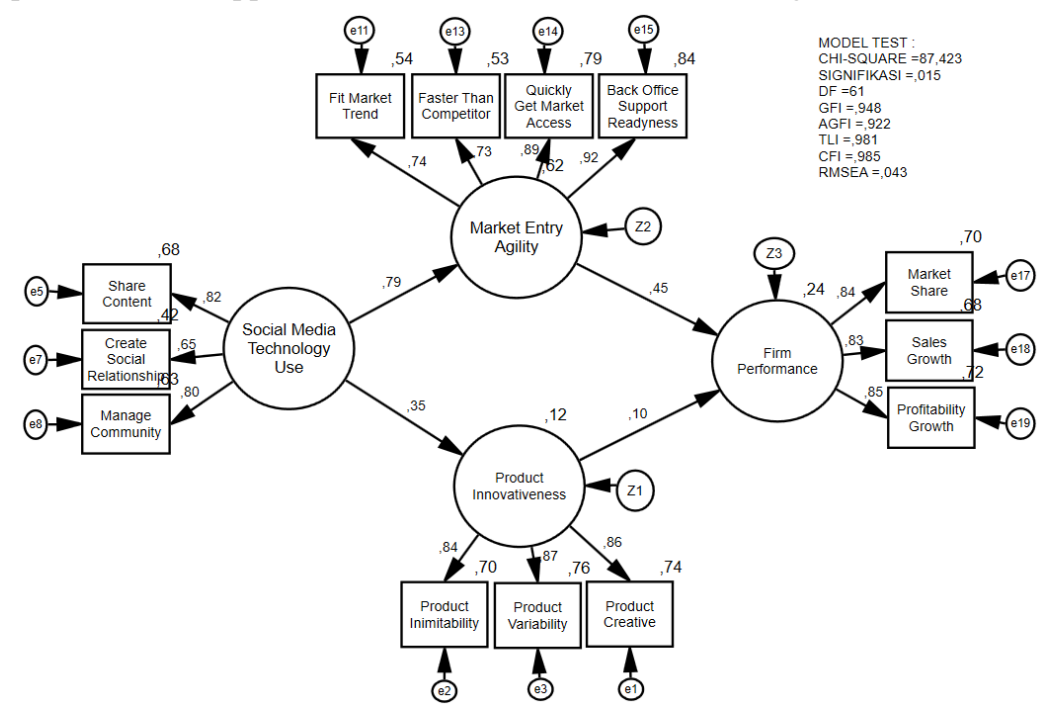

Table 2

Fig. 1. Structural Equation Model Testing

Hypothesis Testing Criteria

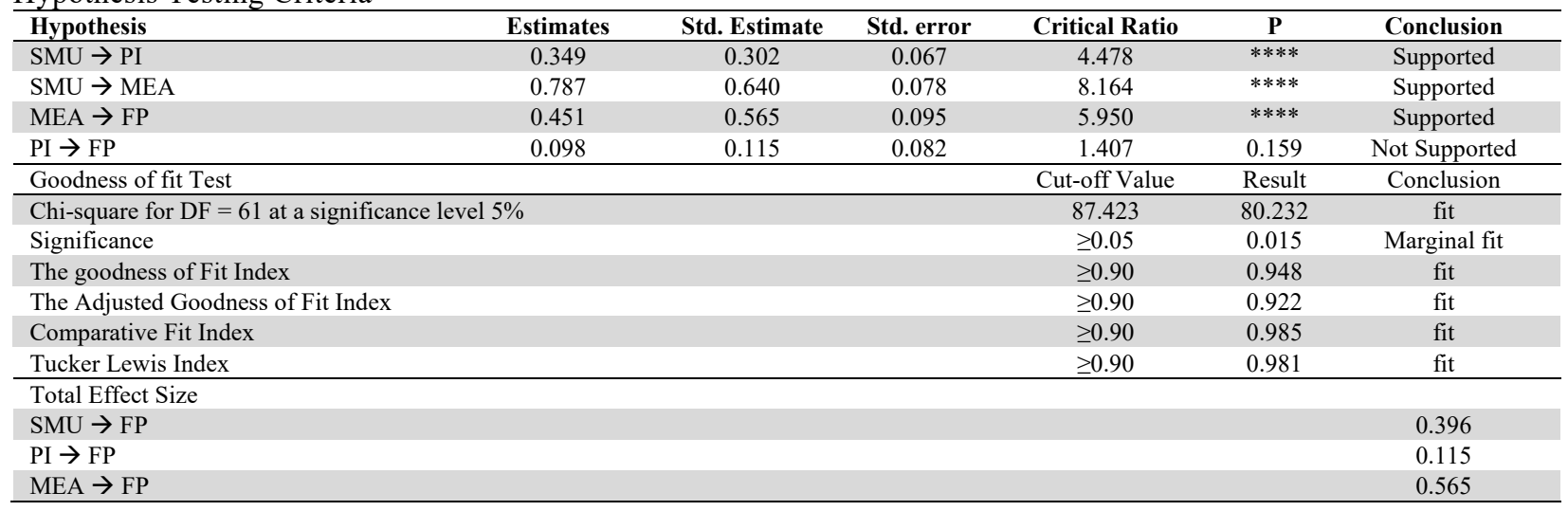

\section{Conclusion and direction for further research}

\subsection{Conclusion}

This study aimed to establish a conceptual model in addressing the research questions on social media technology use that could substantially enhance firm performance with market entry agility \& product innovativeness. The recommended hypothesis acceptance offered specific conclusions on social media technology use management towards high firm performance. The first conclusion involved strengthening the dynamic capability line with and acknowledging digital technology use from tools to capability as to share and collect information for customer information generation (a strategic asset or catalyst for high firm performance). Specifically, the strategic catalyst denoted an efficient instrument to strengthen the agility and research on market entry capability (Nuryakin \& Ardyan, 2018) for high firm performance. 
Second, the underlying logic implied social media technology use to be the first step in capability to enter new market by inducing marketplace incongruencies with speeding to enter the market \& product innovativeness empowerment following the dynamic capability concept (Teece, 2007; Teece, Pisano, \& Shuen, 1997). Social media also implied marketing practices to interact, gather, and share customer and competitor information among companies. As part of a connection, new market development and sustenance within an organization specified an input or driver for high firm performance (Zhang, Gupta, Sun, \& Zou, 2019). Additionally, social media use was acknowledged as an informative and strategic input for high performance with particular business capabilities and practices (collaborating with consumers on co-creation of value, codesign, co-development, and comarketing in new markets) (Sheth, 2020; Zhang et al., 2019). In the current dynamic and intricate business setting, company social media integration and alignment with organizational methods and priorities proved necessary.

Thirdly, the rejection of our hypothesis about the relationship between product innovativeness and firm performance is a turning point since it contributes to the body of knowledge about dynamic capacity. As mentioned in the study of (Hou, Hong, \& Zhu, 2019), impact of innovation will strengthen entrepreneur orientation to enhance firm performance. However, the rejection of the hypothesis becomes an alternative to the new view that product innovation is only the initial way that will indirectly improve marketing performance. Consequently, further examination of marketing science is needed to identify the conceptual variables that affect firm performance.

\subsection{Managerial implication \& limitation}

Study findings offer managerial implication that the SMEs need to concentrate on building effective communicative interaction among the firms' stakeholders, and social media can help achieve the objective effectively. Social media is a costeffective tool to facilitate dealings with stakeholders, building the SMEs' capability to communicate with customers, suppliers, and the public to promote the SMEs image and gain the prospective customer's confidence to deal in a highly competitive business environment. The SMEs need to inculcate a speed and agility to enter new markets through social media to achieve agility to enter new markets and reduced time to enter the market with product innovativeness to offer. The firm-level of innovativeness is also a necessary leverage of a firm's efficiency in product offering and empowering the firms' performance. Enhanced entry agility and reduced time to offer the product in the market facilitate the firms to achieve a competitive edge and improve the firms' performance.

The current study had its strengths in the theoretical and practical contribution made by the current study three prominent limitations associated with the study. Firstly, the current quantitative study assumed few factors of social media usage, market entry agility, product innovativeness and firm performance offering limited generalization of the study model. Future research needs to incorporate more relevant factors of SMEs' risk-taking and proactiveness harnessing the market entry agility, product innovativeness and firms' performance. Secondly, the current study utilized a cross-sectional research design, and singlesourced data instigated the limited generalization of study results. Future research needs to assume longitudinal research design data collected from multiple sources. Lastly, the current study utilized a single country and industry sample, and it would be interesting to explore the study model in other geographic and industrial contexts. It helps to extend the powers of the study model and enhance generalization.

\section{References}

Ahmad, S. Z., Abu Bakar, A. R., \& Ahmad, N. (2019). Social media adoption and its impact on firm performance: the case of the UAE. International Journal of Entrepreneurial Behavior \& Research, 25(1), 84-111. doi:10.1108/ijebr-08-20170299

Al-Rawabdeh, H., Ghadir, H., \& Al-Abdallah. (2021). The effects of user generated content and traditional reference groups on purchase intentions of young consumers: A comparative study on electronic products. International Journal of Data Network Science, 5(4), 691-702.

Alhaimer, R. S. (2021). The Role of Social Media in the Innovation and Performance of Kuwaiti Enterprises in the Food Sector. Journal of Theoretical and Applied Electronic Commerce Research, 16(6), 1960-1972.

Belghitar, Y., Clark, E., \& Kassimatis, K. (2019). A measure of total firm performance: new insights for the corporate objective. Annals of Operations Research, 281(1), 121-141. doi:10.1007/s10479-018-2983-z

Cenamor, J., Rönnberg Sjödin, D., \& Parida, V. (2017). Adopting a platform approach in servitization: Leveraging the value of digitalization. International Journal of Production Economics, 192, 54-65. doi:10.1016/j.ijpe.2016.12.033

Damarwulan, L. M., \& Farida, N. (2018). The Role of Quality of Entrepreneurial Networking and Responsiveness to Global Business Environment in improving the Marketing Performance of Indonesian Exporting SMEs. Quality-Access to Success, 19(165).

Eisenhardt, K. M., \& Martin, J. A. (2000). Dynamic capabilities: what are they? Strategic Management Journal, 21(10-11)

Ferreira, J., \& Coelho, A. (2020). Dynamic capabilities, innovation and branding capabilities and their impact on competitive advantage and SME's performance in Portugal: the moderating effects of entrepreneurial orientation. International Journal of Innovation Science, 12(3), 255-286. doi:10.1108/ijis-10-2018-0108

Flor, C. R., \& Moritzen, M. R. (2020). Entering a new market: Market profitability and first-mover advantages. Journal of 
Corporate Finance, 101604. doi:10.1016/j.jcorpfin.2020.101604

Foltean, F. S., Trif, S. M., \& Tuleu, D. L. (2019). Customer relationship management capabilities and social media technology use: Consequences on firm performance. Journal of Business Research, 104, 563-575. doi:10.1016/j.jbusres.2018.10.047

Garrido-Moreno, A., García-Morales, V., King, S., \& Lockett, N. (2020). Social Media use and value creation in the digital landscape: a dynamic-capabilities perspective. Journal of Service Management, 31(3), 313-343. doi:10.1108/JOSM-092018-0286

Guo, C., Wang, Y. J., Hao, A. W., \& Saran, A. (2018). Strategic positioning, timing of entry, and new product performance in business-to-business markets: do market-oriented firms make better decisions? Journal of Business-to-Business Marketing, 25(1), 51-64. doi:10.1080/1051712x.2018.1424690

Gupta, A., Kumar, A., Grewal, R., \& Lilien, G. L. (2019). Within-Seller and Buyer-Seller Network Structures and Key Account Profitability. Journal of Marketing, 83(1), 108-132. doi:http://dx.doi.org/10.1177/0022242918812056

Hiong, L. S., Ferdinand, A. T., \& Listiana, E. (2020). Techno-Resonance Innovation Capability for Enhancing Marketing Performance: A Perspective of Ra-Theory. Business: Theory and Practice, 21(1), 329-339. doi:10.3846/btp.2020.12117

Hou, B., Hong, J., \& Zhu, R. (2019). Exploration/exploitation innovation and firm performance: the mediation of entrepreneurial orientation and moderation of competitive intensity. Journal of Asia Business Studies, 13(4), 489-506. doi:10.1108/jabs-11-2017-0206

Hunt, S. D., \& Madhavaram, S. (2020). Adaptive marketing capabilities, dynamic capabilities, and renewal competences: The "outside vs. inside" and "static vs. dynamic" controversies in strategy. Industrial Marketing Management, 89, 129139. doi:10.1016/j.indmarman.2019.07.004

Hunt, S. D., \& Morgan, R. M. (1995). The comparative advantage theory of competition. Journal of marketing, $59(2), 1-15$.

Hunter, G. K. (2014). Customer business development: identifying and responding to buyer-implied information preferences. Industrial Marketing Management, 43(7), 1204-1215. doi:10.1016/j.indmarman.2014.06.008

Jimi, P., \& Shijin, Y. (2016). Are competitive reactions changing over time? Management Decision, 54(3), 683-699. doi:10.1108/MD-08-2015-0357

Jones, N., Borgman, R., \& Ulusoy, E. (2015). Impact of social media on small businesses. Journal of Small Business and Enterprise Development, 22(4), 611-632. doi:10.1108/JSBED-09-2013-0133

Kahle, J. H., Marcon, É., Ghezzi, A., \& Frank, A. G. (2020). Smart Products value creation in SMEs innovation ecosystems. Technological Forecasting and Social Change, 156, 120024.. doi:10.1016/j.techfore.2020.120024

Kim, J. (2018). Market entry strategy for a digital platform provider. Baltic Journal of Management, 13(3), $390-406$. doi:10.1108/bjm-07-2017-0228

Latifi, M.-A., Nikou, S., \& Bouwman, H. (2021). Business model innovation and firm performance: Exploring causal mechanisms in SMEs. Technovation, 107, 102274. doi:https://doi.org/10.1016/j.technovation.2021.102274

Leih, S., \& Teece, D. (2014). Market Entry Strategies. Palgrave Encyclopedia of Strategic Management, London.

Li, Y., Li, J., \& Cai, Z. (2014). The timing of market entry and firm performance: A perspective of institutional theory. Industrial Marketing Management, 43(5), 754-759. doi:https://doi.org/10.1016/j.indmarman.2014.04.007

Nash, J. (2019). Exploring how social media platforms influence fashion consumer decisions in the UK retail sector. Journal of Fashion Marketing and Management: An International Journal, 23(1), 82-103. doi:10.1108/jfmm-01-2018-0012

Neirotti, P., Raguseo, E., \& Paolucci, E. (2018). How SMEs develop ICT-based capabilities in response to their environment. Journal of Enterprise Information Management, 31(1), 10-37. doi:10.1108/jeim-09-2016-0158

Nuryakin, \& Ardyan, E. (2018). SMEs' marketing performance: the mediating role of market entry capability. Journal of Research in Marketing and Entrepreneurship, 20(2), 122-146. doi:10.1108/jrme-03-2016-0005

Onufrey, K., \& Bergek, A. (2020). Second wind for exploitation: Pursuing high degrees of product and process innovativeness in mature industries. Technovation, 89. doi:10.1016/j.technovation.2019.02.004

Paparoidamis, N. G., \& Tran, H. T. T. (2019). Making the world a better place by making better products. European Journal of Marketing, 53(8), 1546-1584. doi:10.1108/ejm-11-2017-0888

Pratono, A. H. (2018). From social network to firm performance. The mediating effect of trust, selling capability and pricing capability. Management Research Review, 41(6). doi:10.1108/MRR-03-2017-0080

Presutti, M., Cappiello, G., \& Johanson, M. (2020). Analysing Social Capital and Product Innovativeness in the Relationship Evolution of Born-Global Companies the Mediating Role of Knowledge Acquisition. International Entrepreneurship and Management Journal. doi:10.1007/s11365-020-00663-0

Prifti, R., \& Alimehmeti, G. (2017). Market orientation, innovation, and firm performance — an analysis of Albanian firms. Journal of Innovation and Entrepreneurship, 6(1), 8. doi:10.1186/s13731-017-0069-9

Rajapathirana, R. P. J., \& Hui, Y. (2018). Relationship between innovation capability, innovation type, and firm performance. Journal of Innovation \& Knowledge, 3(1), 44-55. doi:https://doi.org/10.1016/j.jik.2017.06.002

Ramadani, V., Hisrich, R. D., Abazi-Alili, H., Dana, L.-P., Panthi, L., \& Abazi-Bexheti, L. (2019). Product innovation and firm performance in transition economies: A multi-stage estimation approach. Technological Forecasting and Social Change, 140, 271-280. doi:10.1016/j.techfore.2018.12.010

Rezvani, M., Lashgari, M., \& Yadolahi Farsi, J. (2019). International entrepreneurial alertness in opportunity discovery for market entry. Journal of Research in Marketing and Entrepreneurship, 21(2), 76-102. doi:10.1108/jrme-01-2018-0003

Saunila, M. (2020). Innovation capability in SMEs: A systematic review of the literature. Journal of Innovation \& Knowledge, 5(4), 260-265. doi:https://doi.org/10.1016/j.jik.2019.11.002

Sears, J. B. (2019). A real options model of market entry: Endogenous uncertainty and exogenous uncertainty. Journal of International Management, 25(3). doi:10.1016/j.intman.2019.03.003 
Seidel, V. P., Hannigan, T. R., \& Phillips, N. (2020). Rumor communities, social media, and forthcoming innovations: The shaping of technological frames in product market evolution. Academy of Management Review, 45(2), 304-324.

Shehata, G. M. (2020). Exploiting market-oriented collective learning cycle to leverage competitive advantage at a foreign subsidiary in emerging markets. European Business Review, 32(1), 86-128. doi:10.1108/ebr-03-2018-0063

Hunt, S. D. (2010). Marketing theory: foundations. Controversy, Strategy, Resource-Advantage Theory, ME Sharpe, Armonk, $N Y$.

Sheth, J. N. (2020). Borderless Media: Rethinking International Marketing. Journal of International Marketing, 28(1), 3-12. doi:10.1177/1069031x19897044

Spralls, S. A., Hunt, S. D., \& Wilcox, J. B. (2011). Extranet Use and Building Relationship Capital in Interfirm Distribution Networks: The Role of Extranet Capability. Journal of Retailing, 87(1), 59-74. doi:10.1016/j.jretai.2010.09.001

Tabachnick, B. G., \& Fidell, L. S. (2012). Using Multivariate Statistics (6 ed.). New York: Pearson Publisher.

Tajvidi, R., \& Karami, A. (2021). The effect of social media on firm performance. Computers in Human Behavior, 115, 105174. doi:10.1016/j.chb.2017.09.026

Taneo, S. Y. M., Hadiwidjojo, D., Sunaryo, S., \& Sudjatno, S. (2020). Creative destruction and knowledge creation as the mediation between innovation speed and competitiveness of food small and medium-sized enterprises in Malang, Indonesia. Competitiveness Review: An International Business Journal, ahead-of-print(ahead-of-print). doi:10.1108/cr-122017-0090

Teece, D. J. (2007). Explicating dynamic capabilities: the nature and microfoundations of (sustainable) enterprise performance. Strategic Management Journal, 28(13), 1319-1350.

Teece, D. J., Pisano, G., \& Shuen, A. (1997). Dynamic capabilities and strategic management. Strategic Management Journal, 18(7), 509-533.

Trainor, K. J., Andzulis, J., Rapp, A., \& Agnihotri, R. (2014). Social media technology usage and customer relationship performance: A capabilities-based examination of social CRM. Journal of Business Research, 67(6), 1201-1208. doi:10.1016/j.jbusres.2013.05.002

Trivedi, K., Trivedi, P., \& Goswami, V. (2018). Sustainable marketing strategies: Creating business value by meeting consumer expectation. International Journal of Management, Economics and Social Sciences (IJMESS), 7(2), $186-205$.

Vassolo, R., GarcÍA-SÁNchez, J., \& Mesquita, L. (2017). Competitive Dynamics and Early Mover Advantages under Economic Recessions. Revista de Administração de Empresas, 57(1), 22-36. doi:10.1590/s0034-759020170103

Yasa, N. N. K., Adnyani, I. G. A. D., \& Rahmayanti, P. L. D. (2020). The influence of social media usage on the perceived business value and its impact on business performance of Silver Craft Smes in Celuk Village, Gianyar-Bali. Academy of Strategic Management Journal, 19(1), 1-10.

Yasa, N., Giantari, I., Sukaatmadja, I., Sukawati, T., Ekawati, N., Nurcaya, I., Rahanatha, G \& Astari, A. (2021). The role of relational and informational capabilities in mediating the effect of social media adoption on business performance in fashion industry.International Journal of Data and Network Science, 5(4), 569-578.

Zachary, M. A., Gianiodis, P. T., Payne, G. T., \& Markman, G. D. (2014). Entry Timing. Journal of Management, 41(5), 1388-1415. doi:10.1177/0149206314563982

Zhang, H., Gupta, S., Sun, W., \& Zou, Y. (2020). How social-media-enabled co-creation between customers and the firm drives business value? The perspective of organizational learning and social Capital. Information \& Management, 57(3), 103200. doi:10.1016/j.im.2019.103200

Zhang, J., \& Du, M. (2019). Appropriating value from industrial buyer-seller relationships by leveraging network capability. Management Decision, 57(11), 2911-2939. doi:10.1108/md-03-2017-0183

Zhou, Y., Zhang, X., Zhuang, G., \& Zhou, N. (2015). Relational norms and collaborative activities: Roles in reducing opportunism in marketing channels. Industrial Marketing Management, 46, 147-159. doi:10.1016/j.indmarman.2015.01.014

Zollo, L., Filieri, R., Rialti, R., \& Yoon, S. (2020). Unpacking the relationship between social media marketing and brand equity: The mediating role of consumers' benefits and experience. Journal of Business Research, 117, $256-267$. doi:10.1016/j.jbusres.2020.05.001

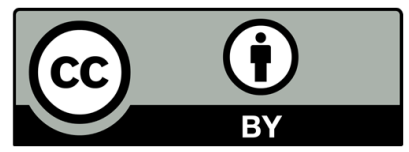

(C) 2022 by the authors; licensee Growing Science, Canada. This is an open access article distributed under the terms and conditions of the Creative Commons Attribution (CC-BY) license (http://creativecommons.org/licenses/by/4.0/). 